\title{
EXPERIMENTAL CIRRHOSIS: LIVER MORPHOLOGY AND FUNCTION
}

DOI: 10.36740/WLek202005120

\author{
Vitalij A. Datsko, Larisa Ya. Fedoniuk, Yana I. Ivankiv, Khristina I. Kurylo, Alina S. Volska, Sergij L. Malanchuk, \\ Oleksandra M. Oleshchuk \\ I. HORBACHEVSKY TERNOPIL NATIONAL MEDICAL UNIVERSITY, TERNOPIL, UKRAINE
}

\begin{abstract}
The aim was to establish the morphofunctional changes of liver in the experimental cirrhosis.

Materials and methods: The research was conducted on 24 white male Wistar rats. Experimental cirrhosis of the liver was simulated by oral administration of $\mathrm{CCl}_{4} 2 \mathrm{~g} / \mathrm{kg}$ 2 times weekly for three months. From the selected fragments of the liver, histological specimens were done according to the conventional method and examined by light microscopy. The activity of the enzymes of cytolysis and cholestasis (ALT, AST, alkaline phosphatase), the content of components of bile (cholesterol, bilirubin and bile acids) were determined in the serum. In the blood and liver were determined the content of the final products of metabolism of nitric oxide: $\mathrm{NO}_{2}$; and $\mathrm{NO}_{3} ;$; in the blood - the content of ceruloplasmin, lactate, pyruvate, middle molecular-weight protein MWP and MWP ${ }_{2}$. In the liver - the activity of succinate dehydrogenase (SDG) and cytochrome oxidase (CHO), N-demethylase and p-hydroxylase microsomal activity. The state of the system of prooxidants-antioxidants was judged by the content in the liver of thiobarbituric acid reactive substance (TBARS), lipid hydroperoxide (LHP), concentration of sulfhydril group (GSH), catalase activities (CAT), superoxide dismutase (SOD). The content of endothelial (eNOS) and inducible (iNOS) NO synthases, the concentration of pro-inflammatory cytokines IL-1 $\beta$, IL-6 and TNF-a were determined by the enzyme immunoassay.

Results: Cirrhosis of the liver, which is morphologically confirmed by the presence of prominent sclerosis in the periportal zones and the formation of umbel, is accompanied by the development of cytolysis and cholestasis processes with an increase in the content of components of bile in the blood (cholesterol, bilirubin and bile acids). An increase in the content of lipoperoxidation products and disturbance of the state of the enzymatic and non-enzymatic units of the antioxidant system, decrease in the activity of mitochondrial (succinate dehydrogenase and cytochrome oxidase) enzymes have been established. The activity of the detoxification processes decreases, namely the inhibition of $\mathrm{N}$-demethylase and p-hydroxylase activity of the liver microsomes, so the manifestations of endotoxicosis increase. This is accompanied with decreased content of endothelial and an increased content inducible NO synthase, a concentration of a stable metabolite of nitric oxide nitrite anion in the blood increase and a decrease in the liver.

Conclusions: Experimental CCl4 cirrhosis is characterized morphologically by sclerosis in the periportal zones and the formation of umbao. The metabolic and functional cirrhotic liver is characterized by cytolysis and cholestasis activation, inhibition of detoxication, prooxidant-antooxidant, including nitrooxidative, disbalance.
\end{abstract}

KEY WORDS: liver, experimental cirrhosis, morphology, functional and metabolic disorders

Wiad Lek. 2020;73(5):947-952

\section{INTRODUCTION}

According to epidemiological studies in Ukraine, the prevalence of chronic liver damage has increased more than 2.5 times in recent decades [1]. Liver cirrhosis is commonly caused by many different forms of liver diseases and conditions, such as chronic hepatitis of viral, toxic or alcohol etiology. [2], impaired hepatic bile duct outflow or mechanical biliary tract obstruction. According to the WHO global liver cirrhosis mortality ranks sixth, in Ukraine - the fifth. Nowadays more than 40 thousand patients with cirrhosis (128 per 100 thousand population) in our country are on dispensary accounting. It is known [3] that the main morphological feature of cirrhosis is the formation of pseudoparticles, which separate the connective tissue layers, furthermore, severity of macrophage infiltration and fatty dystrophy of hepatocytes. Thus, the activated stellate cells, portal fibroblasts, fibrocytes and epithelial cells take part in the formation of fibrous strands [4]. There is also an increase in collagenogenesis, expression of matrix metalloproteinases and their tissue inhibitors. Among the causes that lead to the liver cirrhosis distinguished infectious (viral hepatitis, parasitic diseases of the liver, infections of the biliary tract); toxic and toxic-allergic (alcohol, industrial and food poisoning).

Morphological structure and liver functions predetermined prognostically unfavorable course of the disease due to it complicated pathogenesis and severe clinical manifestations of liver cirrhosis.

\section{THE AIM}

The aim was to establish the morphofunctional changes of liver in the experimental cirrhosis.

\section{MATERIALS AND METHODS}

The research was conducted on 24 white rats of the Wistar line weighing 170-210 g. All the animals received care in compliance with the Guide for the Care and Use of Laboratory Animals (National Institutes of Health Publication No. 85-23, revised 1985). Experiments performed in accordance with the National Institutes of Health Guide for 
the Care and Use of Laboratory Animals and approved by the local animal committee.

Experimental cirrhotic liver damage was modeled by oral administration of $\mathrm{CCl}_{4}$ at a dose of $2 \mathrm{~g} / \mathrm{kg} 2$ times a week for 3 months [5]. Liver scraps were fixed in $10 \%$ neutral-buffered formalin solution for 5 days, embedded in paraffin and sectioned. The scraps were stained with hematoxylin and eosin.

The activity of cytolysis and cholestasis enzymes (ALT, AST, alkaline phosphatase (ALP)), the content of bile components (cholesterol, bilirubin and bile acids) were determined in serum using standard kits of reagents " $\mathrm{Hu}$ man" (Germany). The content of nitric oxide metabolites $\mathrm{NO} 2$ and NO3- was determined in serum and liver [6]. In the blood - the content of ceruloplasmin [7], lactate, pyruvate [8], molecules of average mass $\mathrm{MWP}_{1}$ and $\mathrm{MWP}_{2}$ [9]. In the liver, succinate dehydrogenase (SDG) activity [10] and cytochrome oxidase (CHO), N-demethylase and p-hydroxylase microsomal activity.

The state of the pro-oxidant-antioxidant judged by the concentration of thiobarbituric acid reactive substance (TBARS) [11], lipid hydroperoxides (LHP), concetration of sulfhydryl group (GSH) [12], the activity of catalase (CAT) [13], superoxide dismutase (SOD) activity [14]. Expression of eNOS and iNOS was investigated in serum and liver with ELISA method, using «Enzyme-linked Immunosorbent Assay Kit for Rat Nitric Oxide Synthase 3, Endothelial (NOS3)», Uscn, Life Science Inc, E90868Ra and «Enzymelinked Immunosorbent Assay Kit for Rat Nitric Oxide Synthase 2, Inducible (NOS2)», Uscn, Life Science Inc, E90837Ra respectively, according to the manufacturer's protocol, the concentration of proinflammatory cytokines IL-1 $\beta$, IL- 6 and TNF- $\alpha$ were determined in the blood and hepatocytes.

All the results obtained were processed by the method of variational statistics using the Student's t test (Microsoft Excel XP) and the one-way ANOVA using Origin 7.5 (OriginLab Corp., USA).

\section{RESULTS}

As a result of the investigation, it was found that during experimental cirrhosis in rats, which were injected with tetrachlomethane for three months, macroscopically liver had a dark brown color, it was dense, elastic, multilobular. It was noted, that the structural organization of the liver lobe had undergone some changes. Trabecular (bulk) organization of hepatocytes was disturbed, sinusoidal lumens were slightly expanded, but in some pfilaces capillaries were absent (Fig. 1).

The portal tracts were enlarged because of prominent sclerosis (Fig. 2) and lympho-histiocytic infiltration, in which, in the small groups were observed hepatocytes of various shapes. The growth of fibrous tissue further the formation of regenerating parenchymal nodules surrounded by dense bands of scar and variable degrees of vascular shunting. It can be regarded as zones of compensatory regeneration.

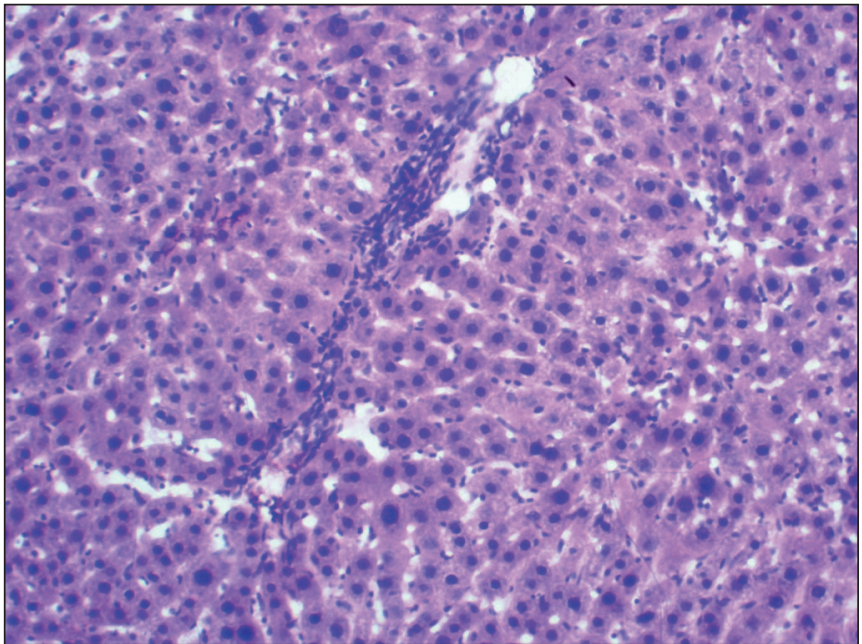

Fig. 1. Formation of portal cirrhosis in parenchyma of the liver. Specimen. Stained with Haematoxylin and eosin $x 100$.

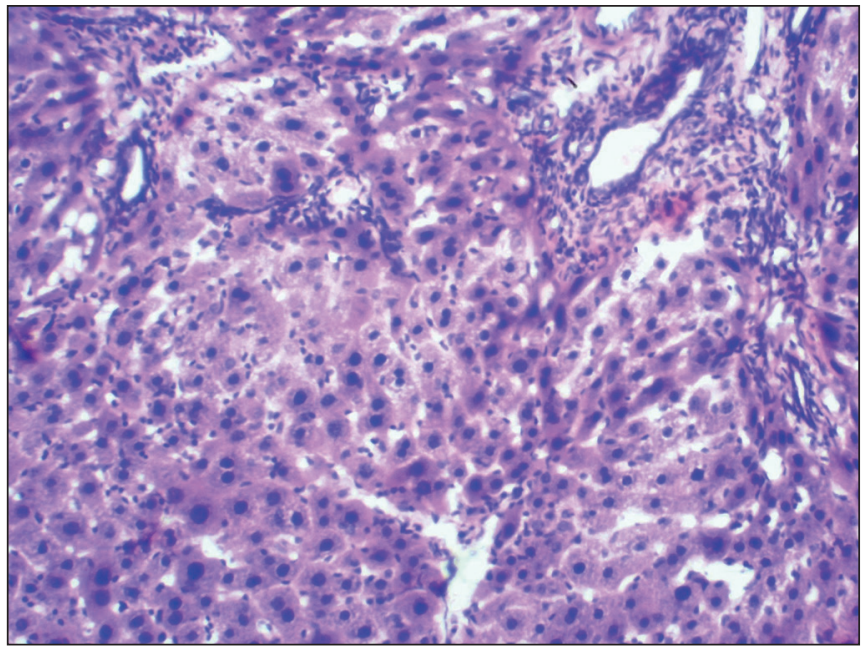

Fig. 2. Sclerosis in combination with lympho-histiocytic infiltration, formation of parenchymal nodules. Specimen. Stained with Haematoxylin and eosin $\times 100$

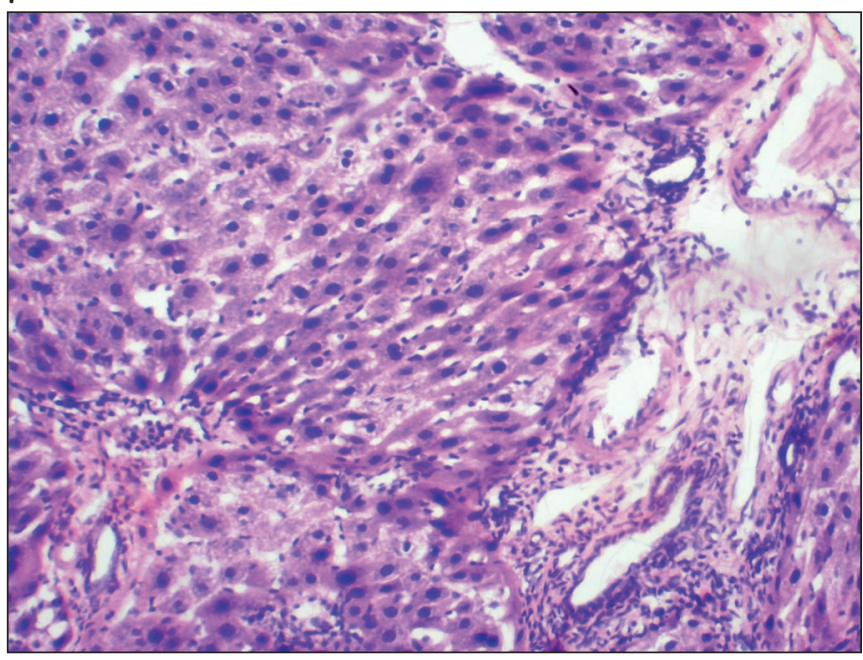

Fig. 3. Hyalinosis and vascular sclerosis, dystrophic changes in hepatocytes, zones of the compensatory hypertrophy. Specimen. Stained with Haematoxylin and eosin x 100 
Table I. Biochemical parameters of serum $(\mathrm{M} \pm \mathrm{m})$

\begin{tabular}{|c|c|c|c|}
\hline Data & Control & Cirrhosis & $\mathbf{p}$ \\
\hline $\mathrm{ALT}, \mathrm{mmol} /(\mathrm{l} \times \mathrm{h})$ & $0.49 \pm 0,10$ & $1.63 \pm 0,05$ & $<0.001$ \\
\hline AST, mmol/(IXh) & $1.68 \pm 0,14$ & $4.90 \pm 0,15$ & $<0.001$ \\
\hline $\begin{array}{c}\text { Alkaline phosphotase, } \\
\mathrm{mmol} /(\mathrm{l} \times \mathrm{h})\end{array}$ & $2,43 \pm 0,086$ & $6.75 \pm 0,30$ & $<0,001$ \\
\hline
\end{tabular}

Notes: Here and following tables $p$ is the probability of difference compared to the control.

Table Il. Content of components of bile in blood $(\mathrm{M} \pm \mathrm{m})$

\begin{tabular}{cccc}
\hline Data & Control & Cirrhosis & p \\
\hline Bilirubin $(\mathrm{mcmol} / \mathrm{l})$ & $6.48 \pm 0.47$ & $26.55 \pm 1.89$ & $<0.001$ \\
\hline Cholesterol $(\mathrm{mmol} / \mathrm{l})$ & $1.81 \pm 0.09$ & $8.58 \pm 0.44$ & $<0.001$ \\
\hline Bile acids $(\mathrm{mg} \%)$ & $234.8 \pm 5.2$ & $296.0 \pm 5.2$ & $<0.001$ \\
\hline
\end{tabular}

Table III. Indicators of the intensity of lipoperoxidation ( $\pm \pm m$ )

\begin{tabular}{cccc}
\hline Data & Control & Cirrhosis & p \\
\hline LHP (liver), UA/kg & $1.77 \pm 0.14$ & $3.67 \pm 0,13$ & $<0.01$ \\
\hline TBARS (liver), $\mathrm{mcmol} / \mathrm{kg}$ & $3.03 \pm 0.08$ & $6.46 \pm 0.47$ & $<0.001$ \\
\hline TBARS (blood), $\mathrm{mcmol} / \mathrm{kg}$ & $2.11 \pm 0.10$ & $3.39 \pm 0.18$ & $<0.001$ \\
\hline
\end{tabular}

Hepatocytes, as the chief functional cells of the liver, were different in shape, some of them did not contain nuclei, cytoplasm of other cells contained nuclei with prominent features of the apoptosis. Liver cells with compensatory hypertrophy were visible in the rest part of the lobules (Fig. 3).
In centrolobular hepatocytes were observed accumulation of abnormal amounts of protein and fine-grained lipid, which indicate degeneration.

Oral administration of the tetrachlormethan also caused changes in the histoarchitectonics of the blood vessels, the walls of which became scleroses and hyalinized. Some vessels were full-blooded with a stasis. These changes indicate disorders of the morphofunctional integrity in the liver tissue.

As a result of biochemical studies it is established that in experimental cirrhosis of the liver, there is an increased in the serum activity of enzymes that are markers of liver damage. The activities of ALT, AST, alkaline phosphotase exceeded the values of the control group of animals in $3.3 ; 2.9$ and 2.8 times, respectively, indicating the development of hepatopathy with manifestations of cytolysis and cholestasis (Table I).

The content of bile components increased in the serum. The concentration of bilirubin, cholesterol and bile acids in cirrhosis exceeded the control indicators in 4.1; 4.7 and 1.3 times (Table II).

It was established that activation of lipoperoxidation processes was observed under these pathological conditions, as evidenced by an increase in the content of TBARS- thiobarbituric acid reactive substances in the affected organ and blood (2.1 times and 60.0\%, respectively) and LHP in the liver (2.1 times) (Table III).

It was determined the decreasing of the activities of antioxidant enzymes in the liver, SOD - by $52 \%$ and catalase - by $54 \%$. The activities of CAT increased by $90 \%$, which reaches the internal cyclic enzyme in the free areas

Table IV. Antioxidant system indicators $(M \pm m)$

\begin{tabular}{|c|c|c|c|c|}
\hline Data & & Control & Cirrhosis & $\mathbf{p}$ \\
\hline Catalase (cat/kg) & \multirow{3}{*}{$\overline{\bar{\Phi}}$} & $4.82 \pm 0.26$ & $2.21 \pm 0.21$ & $<0.001$ \\
\hline SOD (U/kg) & & $3.64 \pm 0.10$ & $1.77 \pm 0.38$ & $<0.01$ \\
\hline $\mathrm{GSH}(\mathrm{mmol} / \mathrm{kg})$ & & $4.29 \pm 1.17$ & $2.56 \pm 0.16$ & $<0.001$ \\
\hline Catalase (cat//I) & \multirow{2}{*}{$\begin{array}{l}\frac{\sigma}{2} \\
\varnothing \\
\varrho\end{array}$} & $11.36 \pm 0.57$ & $21.59 \pm 1.26$ & $<0.01$ \\
\hline Ceruloplasmin (mg/l) & & $241.2 \pm 4.4$ & $208.5 \pm 1.2$ & $<0.05$ \\
\hline
\end{tabular}

Table V. Nitrite and nitrate anion content in blood and liver $(\mathrm{M} \pm \mathrm{m})$

\begin{tabular}{|c|c|c|c|c|}
\hline & \multicolumn{4}{|c|}{ Data } \\
\hline & \multicolumn{2}{|c|}{ blood } & \multicolumn{2}{|c|}{ liver } \\
\hline & $\mathrm{NO}_{2}^{-}(\mathrm{mcmol} / \mathrm{l})$ & $\mathrm{NO}_{3}^{-}(\mathrm{mcmol} / \mathrm{l})$ & $\mathrm{NO}_{2}{ }^{-}(\mathrm{mcmol} / \mathrm{kg})$ & $\mathrm{NO}_{3}^{-}(\mathrm{mcmol} / \mathrm{kg})$ \\
\hline Control & $1.19 \pm 0.05$ & $9.98 \pm 0.23$ & $2.28 \pm 0.11$ & $8.81 \pm 0.34$ \\
\hline Cirrhosis & $3.24 \pm 0.24$ & $11.64 \pm 0.98$ & $1.85 \pm 0.11$ & $7.54 \pm 0.49$ \\
\hline $\mathrm{p}$ & $<0.001$ & $<0.001$ & $<0.05$ & $>0.05$ \\
\hline
\end{tabular}

Table VI. eNOS and iNOS content in blood and liver $(\mathrm{M} \pm \mathrm{m})$

\begin{tabular}{ccccc}
\hline \multirow{2}{*}{ Серія досліду } & \multicolumn{2}{c}{ blood } & & liver \\
\cline { 2 - 5 } & eNOS (U/ml) & iNOS (ng/mл) & eNOS (U/ml) & iNOS (ng/ml) \\
\hline Control & $2.40 \pm 0.13$ & $15.89 \pm 0.73$ & $8.51 \pm 0.49$ & $2.38 \pm 0.21$ \\
\hline Cirrhosis & $0.94 \pm 0.09$ & $64.47 \pm 5,10$ & $4.53 \pm 0.36$ & $5.72 \pm 0.17$ \\
\hline $\mathrm{p}$ & $<0.001$ & $<0.001$ & $<0.001$ & $<0,001$ \\
\hline
\end{tabular}

Note: $1 \mathrm{ml}-1 \times 106$ cells. 
Table VII. Indicators of mitochondrial electron transport and carbohydrate metabolism ( $\pm m$ )

\begin{tabular}{ccccc}
\hline & \multicolumn{2}{c}{ Indicators of mitochondrial activity } & \multicolumn{2}{c}{ Indicators of anaerobic carbohydrate metabolism } \\
\cline { 2 - 5 } & SDH, $\mathbf{~ m m o l} /(\mathbf{k g} \times \mathbf{m i n})$ & $\mathrm{CHO}, \mathbf{m m o l} /(\mathbf{k g} \times \mathbf{m i n})$ & lactate, $\mathbf{~ m o l} / \mathbf{k g}$ & pyruvate, $\mathbf{~ m m o l} / \mathbf{k g}$ \\
\hline Control & $8.99 \pm 0.13$ & $8.86 \pm 0.11$ & $4.95 \pm 0,12$ & $1.32 \pm 0,04$ \\
\hline Cirhosis & $6.84 \pm 0.09$ & $6,648 \pm 0.12$ & $6.52 \pm 0,18$ & $0.64 \pm 0,03$ \\
\hline $\mathrm{p}$ & $<0.001$ & $<0.001$ & $<0.001$ & $<0.001$ \\
\hline
\end{tabular}

Table VIII. Indicators of endotoxicosis and activity of liver microsomal enzymes $(\mathrm{M} \pm \mathrm{m})$

\begin{tabular}{|c|c|c|c|c|}
\hline & \multicolumn{2}{|c|}{ Blood } & \multicolumn{2}{|c|}{ Liver } \\
\hline & $M W P_{1}, U / I$ & $M W P_{2}, U / I$ & $\begin{array}{c}\text { N-demethylase activity, } \\
\mathrm{mmol} /(\mathrm{kg} \times \mathrm{min})\end{array}$ & $\begin{array}{l}\text { p-hydroxylase activity, } \\
\text { mmol/(kg } \times \text { min })\end{array}$ \\
\hline Control & $0.42 \pm 0.01$ & $0.27 \pm 0,01$ & $8.07 \pm 0,19$ & $0.75 \pm 0,02$ \\
\hline Cirrhosis & $0.71 \pm 0.02$ & $0.57 \pm 0,02$ & $4.50 \pm 0,23$ & $0.44 \pm 0,03$ \\
\hline$p$ & $<0.001$ & $<0.001$ & $<0.001$ & $<0.001$ \\
\hline
\end{tabular}

contained in the cyrolytic processes. Serum ceruloplasmin cirrhosis decreased by $18.6 \%$, indicating that inhibition of the synthesis of this copper-containing antioxidant protein in the liver is inhibited. The content of reduced glutathione in the affected organ in this series decreased by $40 \%$, compared with the control indicator (Table. IV).

We have established reduction of nitrite anion in the liver by $18.2 \%$, and in serum growth in 2.7 times. $\mathrm{NO}_{3}$ - level in blood increased by $16.6 \%$ and did not change in the liver (Table. V).

By enzyme immunoassay method was found that the content of endothelial form of NO synthase in the liver and blood decreased by 46.7 and $61.0 \%$, inducible form of NOS enzyme increased 2.5 and 4.1 times, respectively (Table VI). Activation of iNOS can be caused by an increase in the production of the proinflammatory cytokines IL-1 $\beta$, IL- 6 and TNF- $\alpha$, whose levels in cirrhosis exceeded the control values of 3.0; 4.4 and 5.5 times.

The activities of mitochondrial enzymes of SDH and $\mathrm{CHO}$ in the liver decreased by 24.0 and $28.9 \%$, respectively, compared with intact animals, which indicates a disturbance of the processes of energy supply of hepatocytes in cirrhosis.

The level of lactate in the group of animals with cirrhosis increased by $31.7 \%$, and pyruvate decreased by $51.1 \%$, which indicates a disturbance of carbohydrate metabolism and activation of anaerobic glycolysis in liver cirrhosis (Table VII).

Significant inhibition of detoxification processes in the liver was evidenced by a decrease in the rate of $\mathrm{N}$-demethylation and p-hydroxylation processes in the liver by 44.0 and $42.0 \%$, respectively. The increase in serum endotoxicosis in cirrhosis was evidenced by a significant increase in serum levels of both fractions of medium-molecalur weigt proteins: $\mathrm{MWP}_{1}$ (up to $0.71 \pm 0.02$ units/l) and $\mathrm{MWP}_{2}$ (up to $0.57 \pm 0.02$ units/l) - in relation to their level in individuals of the control group - $(0.42 \pm 0.01$ units/l) and $(0.27$ $\pm 0.01 \mathrm{p}$ units/l), respectively (Table. VIII).

\section{DISCUSSION}

The presence of the periportal sclerosis zones and the formation of umbao in the liver lobules, which were indicated using light microscopy after three-month $\mathrm{CCl}_{4}$ administration, indicate the formation of a good model of liver cirrhosis in experimental animals.

The development of this type of hepatopathy with manifestations of cytolysis and cholestasis is proved with increased activity of enzymes that are biochemical markers of liver damage (ALT, AST and ALP) in the serum, which is consistent with the results of other scientists $[15,16]$.

We have found that under these pathological conditions there is a significant increase in the activity of lipid peroxidation process in the structure of membrane hepatocytes. According to modern concepts, the intensification of lipid peroxidation (LPO) is combined with changes in antiradical protection, which is manifested by dysfunction in the system of prooxidants and antioxidants [17]. As a result of the studies, it was found that the activity and content of the components of the antioxidant system of the liver were reduced. Catalase activity of blood significantly increased, indicating the release of the enzyme into the extracellular space in terms of activation cytolysis in cirrhosis. The serum level of ceruloplasmin was decreased by $13.8 \%$, which may be related to the inhibition of hepatic protein synthesis in cirrhosis [18]. It is known that GSH is directly involved in the free radical scavenging, as well as in the recovery of sulfhydryl-containing groups of enzymes such as glutathione peroxidase, glyoxalase and others. Reduction of it content in cirrhosis may be associated with both an increase of LPO in the affected organ and enhancement of glutathione catabolism.

Data of other scientists and the results of our research indicate that, with the activation of LPO processes and the development of hypoxia, most hepatocytes in cirrhosis decreases the energy supply of hepatocytes, due to the separation of the respiration and oxidative phosphorylation in the mitochondria and observed the development of 
their dysfunction. With a lack of oxygen hepatocytes begin to consume the ineffective glycolysis process as a backup mechanism of energy supply, as evidenced by the increase in lactate content in the liver. However, this ultimately leads to the development of metabolic acidosis in cirrhosis, which had been confirmed by other scientists [19].

The decrease in cytochrome 2E1 and 3A activity obtained in our studies indicates a deterioration of liver detoxification function in cirrhosis.

Our previous researches have been dedicated to study the role of nitric oxide system in liver function in normal and various pathological conditions [20,21]. We have observed a decrease in the content of nitrite anion in the liver and a significant increase in blood in cirrhosis. Serum $\mathrm{NO}_{3}$ levels also increased. Activation of NO synthesis in the body can be caused by an increase in the production of proinflammatory cytokines IL- $1 \beta$, IL- 6 and TNF- $\alpha$, the level of which has increased in cirrhosis. In fact, proinflammatory cytokines, which are products of activated macrophages and endothelial cells, have the ability to activate iNOS. NO is formed in the liver under the action of two isoforms - eNOS and iNOS. The pattern of expression and activity of NOS proteins differs among physiological and pathological processes. In chronic liver diseases, there is a significant increase in the activity of inducible NOS isoforms in cirrhosis zones [22]. Thus, the high serum nitrate and nitrite levels in patients with liver cirrhosis and in experimental models are likely to be due to increased concentrations of iNOS-dependent NO. On the other hand, D.C. Rockey and J.J. Chung [23] found a decrease of eNOS activity in rats with tetrachloromethane cirrhosis by $75.0 \%$, which is confirmed by the results presented in this paper. Thus there is a profound change in the cellular distribution of eNOS, which leads to its translocation into hepatocyte nuclei. It can be assumed that, as a result, there is a paradoxical situation in the intrahepatic microcirculation in the flowing blood there is a huge amount of NO, at the same time a sharply increased portal inflow creates additional pressure on the sinus wall, which requires further activation of eNOS and production of nitric oxide in the endothelium of sinusoids. However, this did not happen. Most likely, the increased concentration of NO in the flowing blood by the feedback mechanism dramatically inhibits the expression of eNOS. eNOS-induced vasodilation deficiency was developed, contributing to a decrease in sinusoid diameter and an increase in overall portal vascular resistance. Thus, despite the overproduction of nitric oxide, there is a relative lack of mediator of intrahepatic microcirculation [24], as evidenced by reduction of nitrite anion in the liver that we were obtained in our studies. Our results are consistent with findings of other scientists. Reduced expression of eNOS in the liver in cirrhosis was confirmed the results of immunohistochemically studies A.I. Sarela et al., they showed a significant decrease in the activity of this form of enzyme in patients with liver cirrhosis, who underwent organ transplantation [25]. In our opinion the increase in serum levels of $\mathrm{NO}_{2-}$ and $\mathrm{NO}_{3-}$ are due to activation of iNOS, whose expression is increased in the liver. By reducing the substrate content, the inducible form of NO synthase can also become disjointed and produce reactive oxygen species and exacerbate destructive processes in the liver [26].

\section{CONCLUSIONS}

Cirrhosis of the liver, which is morphologically confirmed by the presence of pronounced sclerosis of the periportal fields and the formation of pseudoparticles, is accompanied by the development of cytolysis and cholestasis processes with an increased content of bile components in the blood, impaired synthesis of urea. The activation of processes of lipoperoxidation, and changes in the enzymatic and non-enzymatic links of the antioxidant system, decreased activity of mitochondrial and microsomal enzymes, endotoxicosis and inflammatory cytokines content in the blood are observed. The decreased in endothelial content and an increased in inducible NO synthase, increasing of concentration of a stable metabolite of nitric oxide nitric oxide in the blood and a decrease in the liver are determined.

\section{REFERENCES}

1. Hybskaya E.U. Suchestvuet li universalnyy Irkarstvennyy preparat dlya lecheniya chronicheskoy patologii pecheni i hepatobiliarnoy sistemy? [Is there a universal drug for the treatment of chronic liver disease and hepatobiliary system?]. Liky Ukrainy. 2012; 5(161):28-30 (UA).

2. Rosen H.R. Clinical practice. Chronic hepatitis ( infection. N. Engl. J. Med. 2011; 364(25):2429-2438.

3. Hernandes-Gea V., Friedman S.L. Pathogenesis of liver fibrosis. Annual Review of Pathology: Mechanisms of Disease. 2011; 6:425-456.

4. Povero D., Busletta C., Novo E. et al. Liver fibrosis: a dynamic and potentially reversible process. Histol. Histopathol. 2010; 25:1075-1091.

5. Doi K., Kurabe S., Shimazu N. Inagaki Systemic histopathology of rats with CCl4-induced hepatic cirrhosis. Laboratory animals. 1991; 25 (1):21-25.

6. Kiselyk I.0., Lucyk M.D., Shevchenko L.U. Osoblyvosti vyznachennya nitrativ I nitrytiv peryferychniy krovi u hvoryh na virusni hepetyty ta pry syndromi zovtyanyci inshoi etiolohii [Peculiarities of the recognition of risks and peripheral blood in patients with viral hepatitis and the syndrome of chronic jaundice of other etiology]. Laboratorna diahnostyka. 2001; 3:43-45 (UA).

7. Kolb V.G., Kamyshnikov V.S. Spravochnik po klinicheskoy chimii [Handbook of Clinical Chemistry]; Minsk, Belarus. 1982; 311. (Ru).

8. Metody biohemicheskich issledovaniy (lipidnyy i energeticheskiy obmen) [Biochemical research methods (lipid and energy metabolism)] / Ed. M.I. Prochrova. Leningrad. 1982; 272. (Ru).

9. Oskina V.V., Chekalina K.I., Gabrielyan N.I. Srednemolekulyarne peptidy spinnimogvoy zidkosti pri gnoynyh meningitah [Medium molecular peptides of cerebrospinal fluid in purulent meningitis] Lab. Delo. 1987; 2:23-25. (Ru).

10. Eshchenko N.D., Volsky G.G. Opredelenie kolichestva yantarnoy kisloty I activnosti sukcinatdegidrogenazy [Determination of the amount of succinic acid and succinate dehydrogenase activity]. In Methods of Biochemical Researches; Publishing House of Leningrad University: Leningrad, Russia. 1982; 207-212 (Ru).

11. Andreeva L.I., Kozhemyakin L.A., Kiskun A.A. Modifikatsiya metoda opredeleniya perekisey lipidov $v$ teste $s$ tiobarbiturovoy kislotoy [Modification of the method for determining lipid peroxide in the test with thiobarbituric acid]. Lab. Delo. 1988; 11:41-43 (Ru). 
12. Gavrilov V.B., Mishkorudnaya M.I. Spektrofotometricheskoe opredelenie soderzaniya gidroperekisey lipidov [Spectrophotometric determination of lipid hydroperoxide in the blood plasma]. Lab. Delo. 1983; 3:33-35 (Ru).

13. Korolyuk M.A., Ivanova L.I., Mayorova I.G., Tokarev V.E. Metod opredeleniya aktivnosti katakazy [Method for determination of catalase activity]. Lab. Delo. 1988; 1:16-19 (Ru).

14. Chevari C., Csaba J., Sekey J. Rol' superoksidismutazy v okislitelnych procesach kletki I metod opredoleniya yeye v biologicheskih materilach [The role of superoxide dismutase in oxidative processes in cells and the method of its determination in biological materials]. Lab. Delo. 1985; 11:678-684 (Ru).

15. Bezborodkina N.N., Okovityy S.V., Kudryavceva M.V. et al. Morfometriya mitokhondrial'nogo apparata gepatotsitov normal'noy i tsirroticheski izmenennoy pecheni krys [Morphometry of the mitochondrial apparatus of hepatocytes of normal and cirrhotically altered rat liver]. Citologiya. 2008; 50(3):228-236 (Ru).

16. Sydorchuk L., Yarynych Y., Fedoniuk L. et al Hepatocytes' Function and Adipokines in Patients with Non-alcoholic Fatty Liver Disease Depending on the ACE (rs4646994) and PPAR-2 (rs1801282) Genes'Polymorphisms. Rev. Med. Chir. Soc. Med. Nat., laşi. 2018; 2:358-364.

17. Forrester S.J., Kikuchi D.S., Hernandes M.S. et al. Reactive Oxygen Species in Metabolic and Inflammatory Signaling. Circ Res. 2018; 122(6):877-902.

18. Da-Wu Zeng, Jing Dong, Jia-Ji Jiang et al. Ceruloplasmin, a reliable marker of fibrosis in chronic hepatitis $B$ virus patients with normal or minimally raised alanine aminotransferase. World J Gastroenterology. 2016; 22(43):9586-9594.

19. Belyavsky V.V., Rogovyy Yu.Ye. Patogenez hepatorenalnogo syndromy [Pathogenesis of hepatorenal syndrome]. Bukovyn. med. visnyk. 2010; 3(55):119-123 (UA).

20. Oleshchuk 0.M. The impact of modulators of nitric oxide synthesis on biochemical indices of liver in rats. Fiziolohichnyĭ zhurnal. 2014; 60(2):57-62.

21. Oleshchuk OM. Protective effect of ischemic preconditioning on hepatic state in its ischemic-reperfusion injury. Klin Khir. 2013; 4:76-8.

22. Sarela A.I., Mihaimeed F.M., Batten J.J. Hepatic and splanchnic nitric oxide activity in patients with cirrhosis. Gut.1999; 44:749-753.

23. Rockey D.C. Reduced nitric oxide production by endothelial cells in cirrhotic rat liver: endothelial dysfunction in portal hypertension. Gastroenterology. 1998; 114:344-351.
24. Wiest R. The paradox of nitric oxide in cirrhosis and portal hypertension: too much, not enough. Hepatology. 2002; 35(2):478-491.

25. Wang J.J., Gao G.W., Gao R.Z. Effects of tumor necrosis factor, endothelin and nitric oxide on hyperdynamic circulation of rats with acute and chronic portal hypertension. World J. Gastroenterol. 2004; 10 (5):689693.

26. Heush P., Aker S., Boenger K. Increased inducible nitric oxide synthase and arginase II expression in heart failure: no net nitrite/nitrate production and protein S-nitrosylation. Am. J. Physiol. Heart Circ. Physiol. 2010; 299:446-453.

The work is carried out within the framework of the initiative research work of the I. Horbachevsky Ternopil National Medical University "0119U000617 Pharmacological study of cardio- and gastroprotective effects of biotechnological, herbal and synthetic drugs".

\section{ORCID and contributionship:}

Vitalij A. Datsko - ${ }^{B, C, D}$

Larysa Ya. Fedoniuk - 0000-0003-4910-68 $88^{E}$

Yana I. Ivankiv - 0000-0002-2717-9843 ${ }^{\mathrm{D}}$

Khristina I. Kurylo - 0000-0002-7799-0618 ${ }^{D}$

Alina S. Volska - 0000-0002-4985-9559 B,C

Sergij L. Malanchuk ${ }^{B}$

Oleksandra M. Oleshchuk - 0000-0002-1491-1935 A,E,F

\section{Conflict of interest:}

The Authors declare no conflict of interest

\section{CORRESPONDING AUTHOR Larysa Ya. Fedoniuk \\ Medical Biology Department, \\ I. Horbachevsky Ternopil National Medical University \\ Valova street, 9, Ternopil, 46000, Ukraine \\ tel: +380673999143 \\ e-mail: Fedonyuk22Larisa@gmail.com}

Received: 27.01 .2020

Accepted: 01.04 .2020

A - Work concept and design, B - Data collection and analysis, C - Responsibility for statistical analysis,

D-Writing the article, $\mathbf{E}$-Critical review, $\mathbf{F}$ - Final approval of the article 